\title{
プロック被覆工による波高減衰と作用波力の特传について \\ Effect of Wave Attenuation of Modeled Armor Blocks and \\ Wave Force on Them
}

小野正順*・出口一郎・・椹木 亨*

Masanobu. 0no, Ichiro. Deguchi and Toru. Sawaragi

\begin{abstract}
Submerged breakwaters, one of the coastal protection works, are usually constructed by rubble stones of relatively small size and armor blocks which cover rubble stone. In order to discuss the stability of submerged breakwaters and the effect of submerged breakwater on wave attenuation, function of armor blocks for controlling fluid motion and wave force on them have to be fully analyzed.

In this paper, we simplify the armor blocks on the crown of the submerged breakwater by using flat plate with openings. Flow pattern around opening, energy loss on the plate and wave force on the plate are investigated through experiments
\end{abstract}

Keywords:Armor block on submerged breakwater, Wave force on armor block,

1.はじめに

近年、海岸保全対策工法の一つとして用いられてきている幅広潜堤は、通常比較的重量の小さい捨石などを中 詰めとし、その表面を重量の重い被復エブロックで被覆する構造で建設される。従って、来襲波による被災を防 ぐためには、まず被復エブロックの安定性について検討する必要がある。また、波浪制御効果についても幅広潜 堤が、透水性の異なる潜堤構成材料と被覆エブロックで構成されていることから、従来研究されているような一 様な透水層で構成された潜堤による波浪制御効果だけではなく、その表面の被復エブロックによる波浪制御効果 についても考虑する必要がある。そのためには、被夏工下倒の流体に、どの程度波動運動が伝播されているのか を明らかにしておく必要がある。

本研究では、このような被徣工を、空㸺を有する水平板に置き換えることにより、その透水性による波高隇衰 効果、被覆エブロック周辺の流速分布、及びブロックに作用する波力について実験的に明らかにすると共に、大 型構造物に対して適用性が確認されているポテンシャル理論に基ゔく G r e e n 関数法を用いて数值計算を行い、 各特性量に対する非ポテンシャル的な流体運動による影滦を明確に示した。



四-1 被頁工と波高計の設置状況

\section{2. 実験装置及び実験方法}

実験水槽は、図一 1 に示す長さ $30 \mathrm{~m}$, 愊 $0.5 \mathrm{~m}$, 高さ $1.2 \mathrm{~m}$ の 2 次元造波水槽を用いた。空隙を有する被復工の模型は、 水平板でモデル化され長さ $\mathrm{B}=7.56 \mathrm{~m}$ 。幅 $0.5 \mathrm{~m}$, 厚さ $1.2 \mathrm{~cm}$ の防水べニヤに半径 $\mathrm{r}=2.7 \mathrm{~cm}$ の内形の空隙を設けて作成し、 造波機加ら約 $21 \mathrm{~m}$ の所に水平に設置した。被覆工の空隙の形状及び置は、図ー2に示す 3 種類とし、空隙率 $\alpha$ は 7. 2.14.4.28.8\%である。水深hは $30 \mathrm{~cm}$ 、入射波周期 Tは $1.1 \mathrm{sec}$ とし、被得工設置位置 $\mathrm{R}$ を $5,10.15 \mathrm{~cm}$ の 3 種類、波形 勾配を0.01〜0.05の3 種類に变化させ、いずれる非碎波の条件で実験を行った。この波条件て、被覆工は入射波

* 正会具 大阪大学工学部土木工学科（T565 吹田市山田丘2-1） 
波長に対して十分大きい長さ（B/L=4.6）を有し、入射波波長に対して十分 小さい空隙徍 $\mathrm{r}(\mathrm{r} / \mathrm{L}=0.017)$ で空隙が空けられている。被復工上での波高隇 衰を测定するため、被椱工上のほぼ0.9m間隔の 9 地点（図中 $A \sim 1$ 地点）で 波高の测定を行った。流速は、被復工中央部（E地点）の空渻部において、 釣直方向に被覆工から上下 $0.5 \mathrm{~cm}$ 離れたところから $1 \mathrm{~cm}$ 間隔に 6 地点、さらに そこから $2 \mathrm{~cm}$ 閒隔に测定できる範囲の水平・釣直流速を测定した。被復エブ ロックに作用する揚力は、被夏工中央部（E地点）における被覆工を一部切 り取り、そのセグメントに作用する揚力を片持ち梁形式の波力計により测定 した。一方、被覆エブロックを緩傾斜護岸として用いる場合を想定して、護 岸としての波の通過あるいは反射特性について実呀を行った。この場合、被 得工の法面勾配としては、現地で施工されている緩倾斜護岸の法面勾成1/3 〜1/6程度を考虑して、1/3,1/6,1/10の3種類に变化させた。護岸の反射率 の测定は反射波侧に設置した 2 本の波高計のデータ から入反射波分嚁法を用いて测定した。

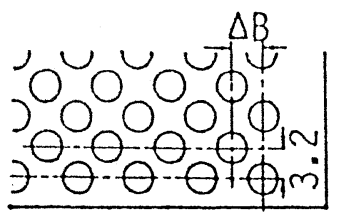
UNIT: $\mathrm{cm}$ WAVE 空隚率 $28.8 \%$


空隚率 $14.4 \%$

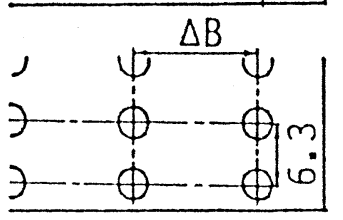

空隍率

$7.2 \%$

図-2 被瞿エブロックの模型 （空隙径 $\mathrm{r}=2.7 \mathrm{~cm}$ )

\section{3.ポテンシャル理論に基づく解析法}

ポテンシャル理論に基づく解析法としては、薄肉 物体にも適用できる 2 次元 $\mathrm{Gr}$ e e n 関数法 ${ }^{1}$ を用 いた。解析に用いた被覆工の錚直 2 次元解析モデル は、図一 3 に示すように空隙の間隔 $\Delta B$ を模型と等 しくとり、実験模型と解析モデルの空隙率が等しく なるように解析モデルにおける空隙幅Dを決定した。

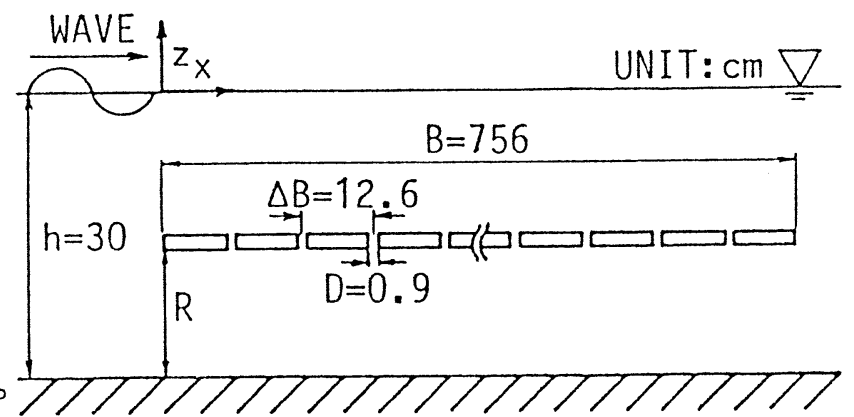

図-3 被復工の 2 次元解折モデル（空隙率7.2\%）



(a) 筀隙率 $\alpha=7.2 \%$ の場合における被覆工天端上の 波高分布を回折係数 $\mathrm{K}$ Dの分有と して示したものである。図(a). (b) は各々被雵工の空隙率が $\alpha=$ 7. $2 \%, 28.8 \%$ の場合を示し、各 図中の 3 種類の記号口, $\triangle$. Oは、 が0.01，0.03，0.05の場合を示す。0.4 各図より被翟工の設置水深に夙 係なく波形勾配が大きいほど波 高の減衰が大きく、その特性は 設圈水深が大きく、空腺漯が小

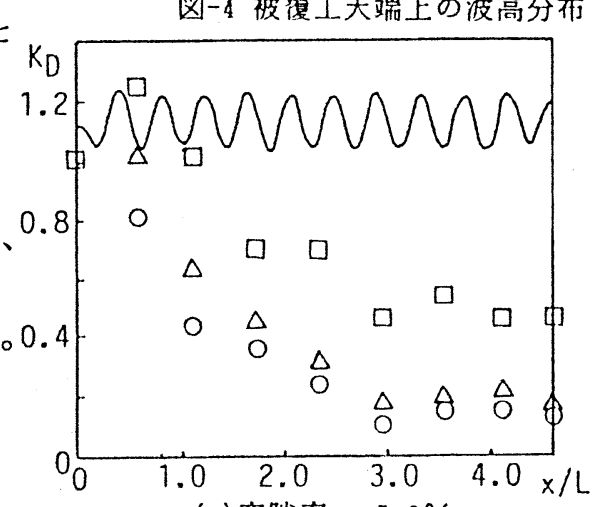

(a) 空隙浑 $\alpha=7.2 \%$



(b) 空隙率 $\alpha=28.8 \%$

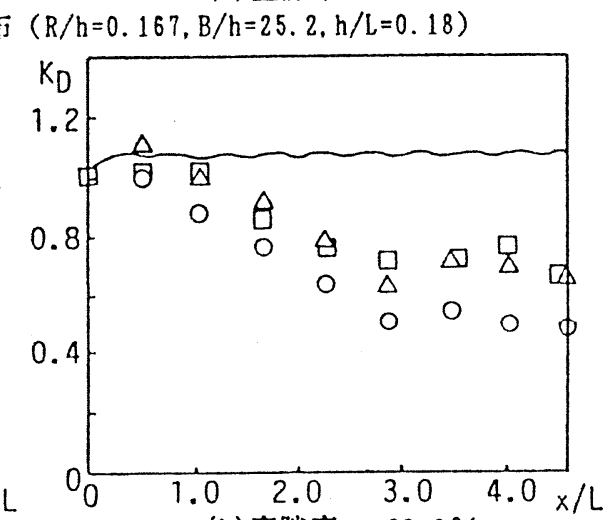

(b) 空隐率 $\alpha=28.8 \%$

图-5 被得工天端上の波高分有（ $R / h=0.5, B / h=25.2, h / L=0.18)$ さい程明確に現れる。これは、エネルギー逸散を生じると考えら机る空隙が、水粒子速度のより大きい水面近く に位置するためで、波高が大きく波形勾西が大きい場合に波高減衰が大きいのも同様な理由である。また、被樭 工の空隙の数が少ない（空隙染が小さい）場合空隙での縮流効果によって大きなエネルギー逸散を生じ、空隙の 数を增やす（空腺萍を大きくする）と空腺での縮流効果があまり激しくなくエネルギ一逸散は小さくなるすのと 考えられる。よって、空隙莎の小さい場合の波高減衰は、入射波波高の影幚を受け易いものと考えられる。従っ て、被復工天端上の波高減衰は、各ヶースとも波高の大きい沖側部分で急激に減少し、岸侧部分では減衰が小さ 
い。特に、 $\mathrm{R} / \mathrm{h}=0.5$ の場合は、 空隙皐に関わらす沖侧から波長 の 3 倍程度までは波高隇衰が大 0.8 きく、その後の岸测部分では、 0.6 ほとんど波高は減衰せずK。の 值も重複波程度にばらつきを生 じる。一方、G r e e n 関数法 0.2 による算定結果は、入射波之回 折波との重权合わせにより被覆

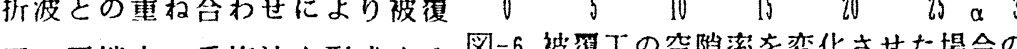

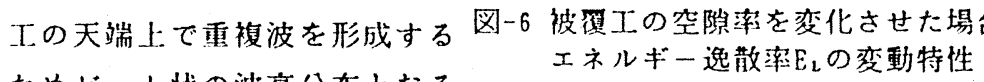
ためビート状の波高分布となる。

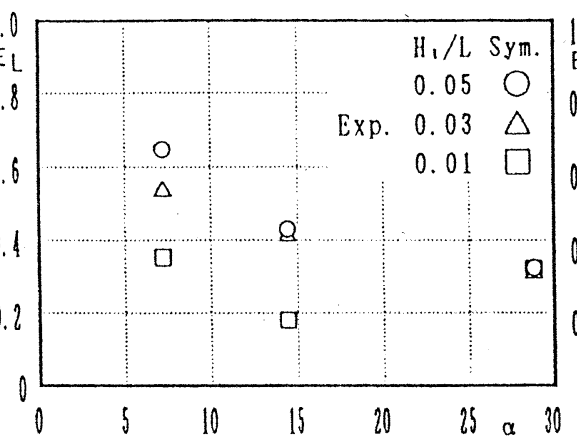

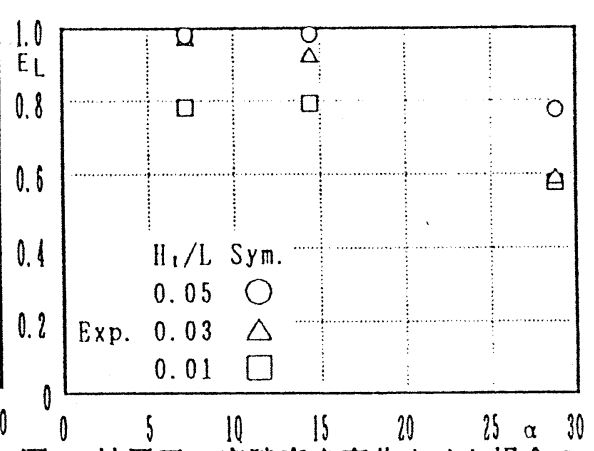

被覆工の空隙垹を变化させた場合の エネルギー逸散㵖 $\mathrm{E}_{\mathrm{L}}$ の変䡃特性 $(\mathrm{R} / \mathrm{h}=0.5, \mathrm{~B} / \mathrm{h}=25.2, \mathrm{~h} / \mathrm{L}=0.18)$

実験結果においては、十分な测定点が無いためこれらの波高分布が生しているかどうかはわからないが、重缼波 程度のK。のばらつきが波高の減衰した岸则付近でみられ、拈そらく波高の減衰に重複波の波高分布が重悋合って いると考元ら机る。従って、実験では回折波による波変形より、非ポテンシャル的エネルギー逸散が卓越してい ることがわかる。また、円形の空隙形状を同じ空隙率を有する正方形の空隙形状でモデル化し、3次元形状を考 虑できる G r e e n 阙数法 ${ }^{2}$ を用いて解析した算定結果は、上述した 2 次元解析モデルとほぼ同様な算定結果で あったことを付記しておく。図ー6と7は、それぞれ被覆工の設置位置が $\mathrm{R} / \mathrm{h}=0.167, \mathrm{R} / \mathrm{h}=0.5$ の場合における被得 工の空隙㴖 $\alpha$ を変化させた場合のエネルギー逸散摔 $\mathrm{E}_{2}$ の变動特性を示す。エネルギ一逸散を算定するに当たり、 反射率は 0 と仮定している。罒より被覆工の設置位置に関係なく空隙率が小さいほど波高減衰が大きく、エネル ギー逸散を生じると考えられる空隙の個数を增やしても必ずしも波高隇衰は大きくならないことがわかる。しか し、空陌がなければ波高隇衰は被徣工の表面抵抗によるるののみでほとんどないと考えられることから、エネル ギー逸散が最大となる空隙菜が存在し、その值は本研究で対象としている被復工に対して10\%程度であることが わかる。これは非常に小さな值であり、被得工に空隙があることによってその天端上を伝播する波は急激に減衰 を生じることがわかる。
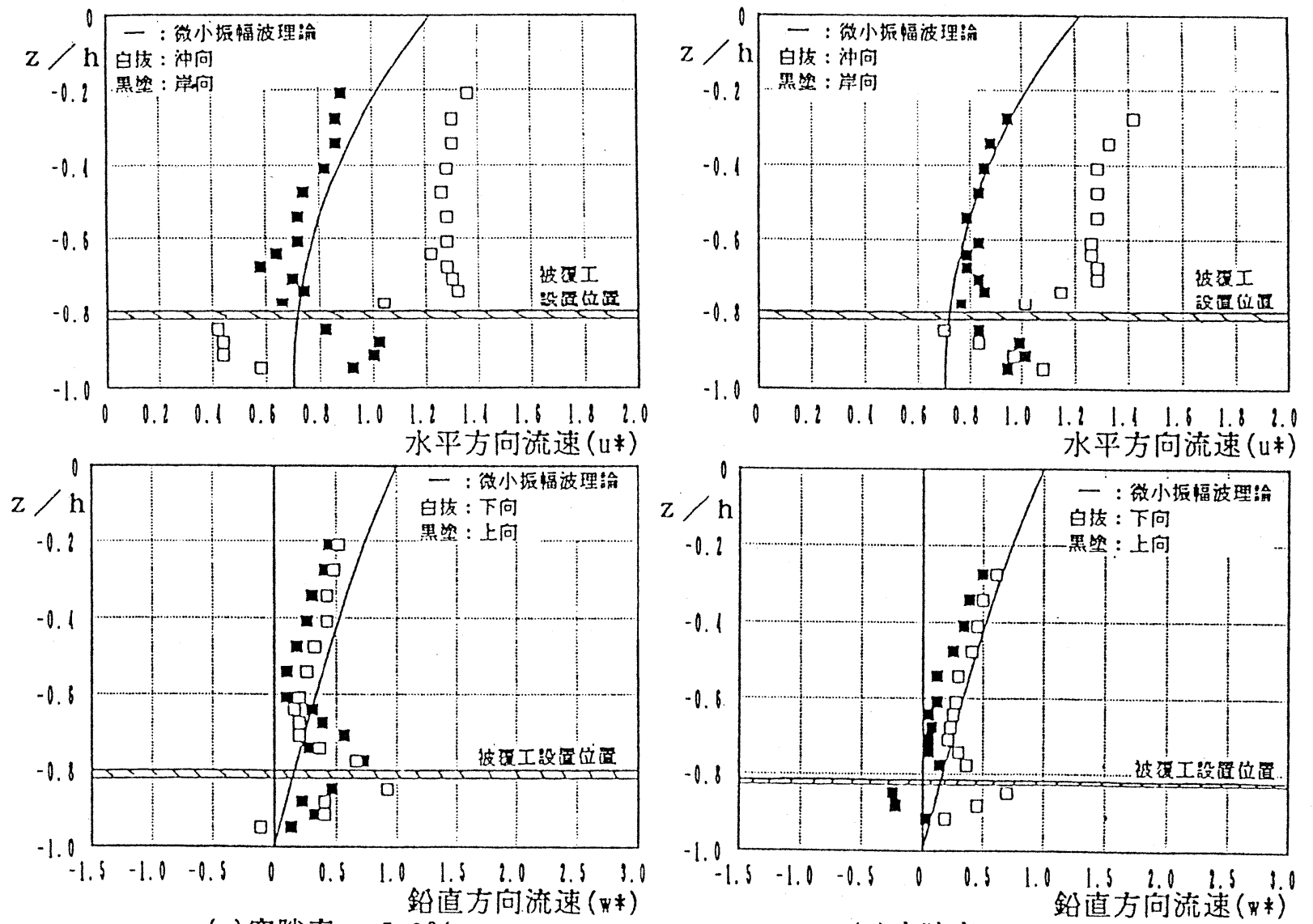

(a) 空隙率 $\alpha=7.2 \%$

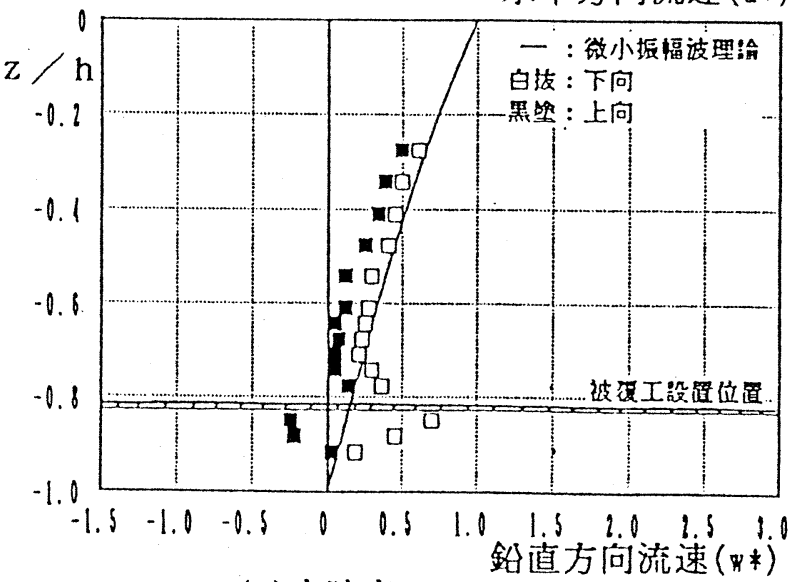

(b) 空腺深 $\alpha=28.8 \%$

図-8 被裂工周辺の流速分布 $\left(H_{1} / L=0.01, R / h=0.167, B / h=25.2, h / L=0.18, h / L=0.03\right)$ 



(a) 空隙率 $\alpha=7.2 \%$

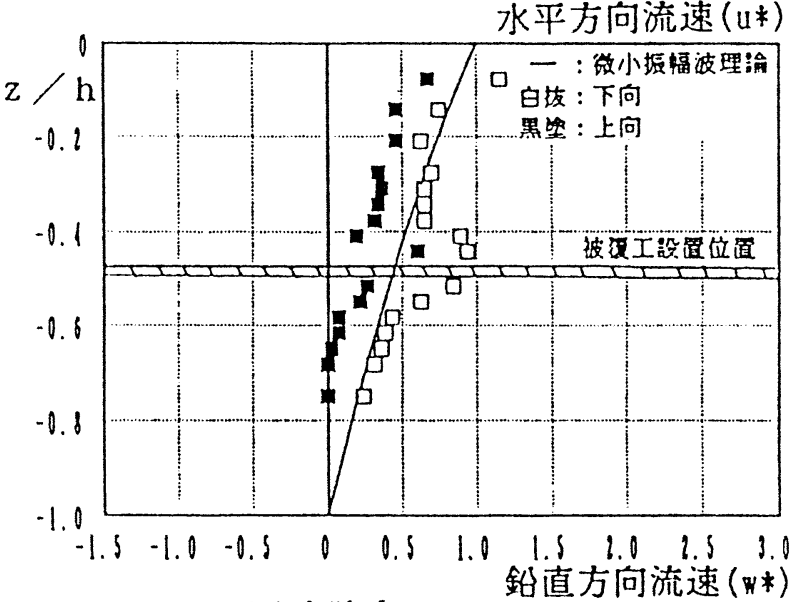

(b) 空隙率 $\alpha=28.8 \%$

図-9 被復工周辺の流速分布 $\left(\mathrm{H}_{\mathrm{t}} / \mathrm{L}=0.01, \mathrm{R} / \mathrm{h}=0.5, \mathrm{~B} / \mathrm{h}=25.2, \mathrm{~h} / \mathrm{L}=0.18, \mathrm{~h} / \mathrm{L}=0.03\right)$
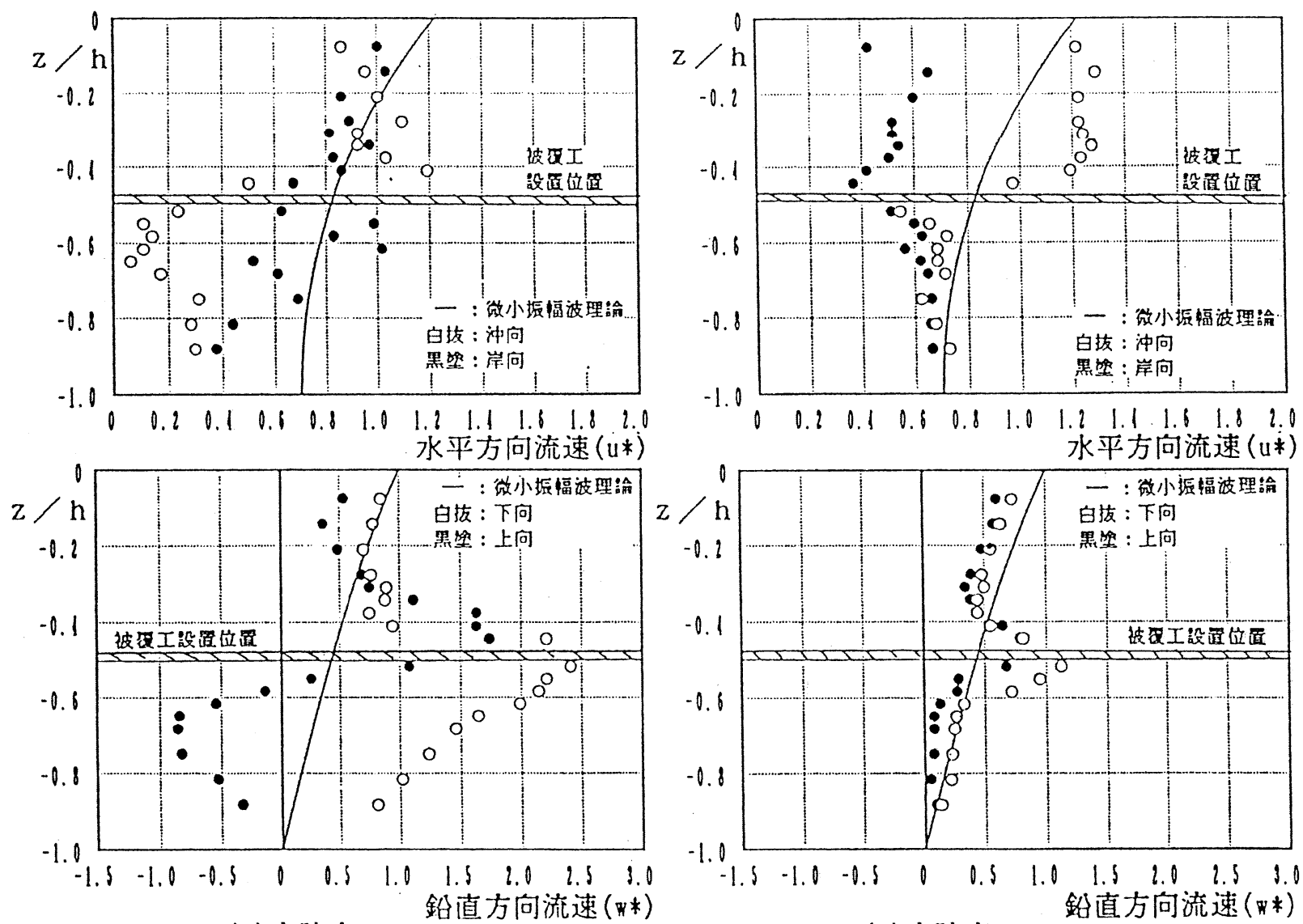

(a) 空隙率 $\alpha=7.2 \%$

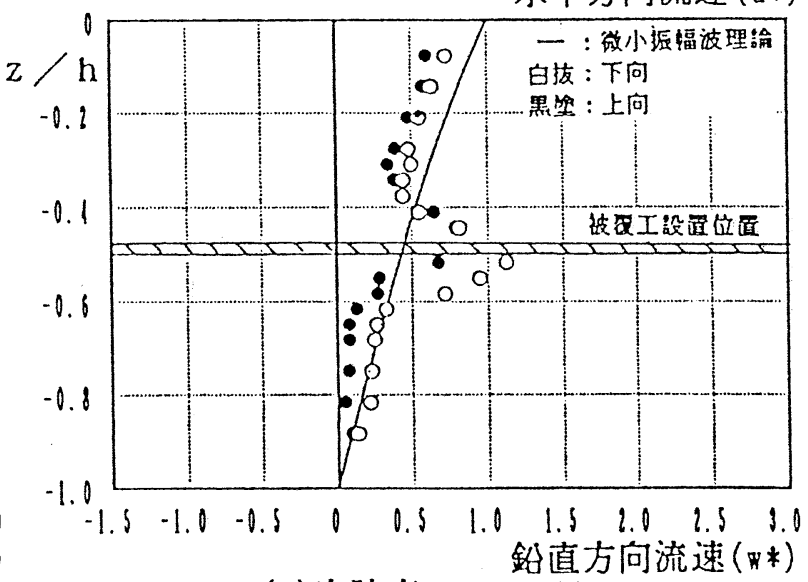

図-10 被覆工周辺の流速分布 $\left(H_{\mathrm{l}} / \mathrm{L}=0.05, \mathrm{R} / \mathrm{h}=0.5, \mathrm{~B} / \mathrm{h}=25.2, \mathrm{~h} / \mathrm{L}=0.18, \mathrm{~h} / \mathrm{L}=0.03\right)$ 


\section{2 被覆工周辺の流速分有の特性}

図-8と 9 は、 $H_{\mathrm{t}} / \mathrm{L}=0.01$ で各々被覆工の設置水深が $\mathrm{R} / \mathrm{h}=0.167,0.5$ の場合における図 -1 中の $\mathrm{E}$ 地点の釣直方

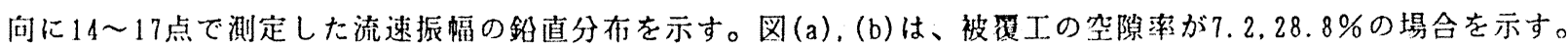
各上図が水平方向流速、下図が鉣直方向流速を示し、水平方向流速にっいては、図中の記号で白报が沖向、黑染

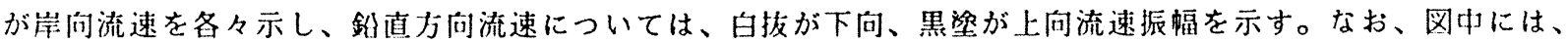
被覆工を設置しない場合の微小振幅波理論によって求められる解も併せ示している。各流速は、测定地点 $\mathrm{E}$ 点て

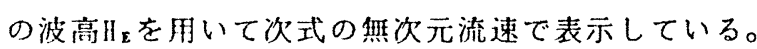

$$
(\mathrm{u} *, w *)=(\mathrm{u}, \mathrm{w}) /\left(\sigma \mathrm{H}_{\mathrm{E}} / 2\right)
$$

各図の水平方向流速の沖向方向流速の增加は、波の有限振幅性の効果であると考えられる。人射波あるいは被 覆工天端上の波の相対水樑 $\left(\mathrm{h} / \mathrm{L}_{\mathrm{I}}\right)$ は、0.18,0.09程度であり、比較的波の峰がとがった谷の平坦な波である。図一 8 の設置水深が小さい場合、空隙㳯の小さい方が被覆工周辺の釣淔流速が多少大きくなっているが、空隙率の変 化に伴う水平・釣直流速振幅の空間分布の变化はあまり明確には現㣗ていない。図一-9の設置水深が大きい場合 あ、空隙率の大きい場合は被覆工周辺で釷直流速振幅の多少の增大がみら机るがその增幅される範囲や增大量は あまり大きくなく、空隙における縮流効果は明確に生じてはいない。しかしながら、空隙率が小さい場合、特に

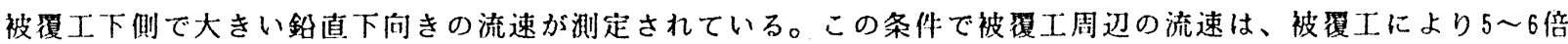
程度に加速さ机、その範团は被覆工内部から天端上水深の中ごろまで及ぶ。この特性は、図一 9 と同様な条件で $H_{1} / \mathrm{L}=0.05$ の場合の図-10kついても同様に見られる。そして、空隙津の大きい場合についても、被覆工周辺の 釣直力问流速振幅は、波形勾配が小さい場合と比較すると大きくなっている。この被覆工周辺の鈆直流速振幅の 增大により空隙周囲には剥雖渦が生していることが容易に想像できる。これらの乱机によって天端上を伝濖する 波は隇衰させられると考えられ、これは空隙率7.2\%でエネルギー逸散が極大值となることで裹付けている。

\section{3 被夏プロックに作用する波力の特性}

被稪工中央部の被覆ブロックに作用する揚力は、被 覆工中央部の波力セグメントに作用する揚力として测 定され、そこで测定された波高筐を用いた次式の無次 元波力 $\overline{F^{\mp}}$ で表示する。

$$
\overline{F^{\natural}}=\frac{\bar{F}}{\rho g \frac{H_{E}}{2} S_{1} S_{2}(1-\alpha)}
$$

上式で、 $S_{1} ， S_{2}$ は波力セグメントの樅横の長さを示 す。

図一 11 は、空隙率 $\alpha=14.4 \%$ 被覆工を設置水深 $\mathrm{R} / \mathrm{h}=0.5$ で設置した場合の被覆工中央部のブロックに 作用する揚力の $\mathrm{k} \mathrm{h}$ による变動特性を示したものであ る。作用させた波の波形勾配は、0.03〜0.05程度の波を作用させた。 図中の白抜の記号で示さ狆る実験結果は上问波力を、黑游は下向波 力を表す。本論文で対象としている波条件（ $\mathrm{T}=1.1 \mathrm{sec} ）$ は、 $\mathrm{k} \mathrm{h}=1$. 15である。図中には、ポテンシャル理論から求められる被復ブロッ クに作用する慣性力（鉛直方向波力）についても例せて示している。 図より、本研究で対象としている波条件に対して被得ブロックに作 用している揚力は、抗力ょり慣性力が卓越している領域であること がわかる。そして、本波条件より長周期波侧では抗力による波力が 惯性力による波力を上回り、予测される惯性力以上の波力が作用す る可能性がある。図-12 は、被淀工設置位置が $\mathrm{R} / \mathrm{h}=0.333$ の場合に おいて被顠工の空腺率を变化させた場合の被嗄ブロックに作用する 揚力の変動特性を示す。図より、空隙沸が小さくても波形勾配が小 さければ、ほとんど慣性力によって作用波力が予测できることがわ かる。比較的大きい抗力が作用するのは、設置水深 $\mathrm{R} / \mathrm{h}=0.333$ の場 合で空腺深が小さくかつ波形勾配の大きい場合であり、かなり激し



因-12 被覆工の空腺染を变化させた場合の 被劕ブロックに作用する揚力の变動特性 $(R / h=0.333, B / h=25.2, h / L=0.18)$ 
い波浪条件でないと慣性力を上回る大きな抗力は作用しないと考え られる。さらに、被覆工設置位置が $\mathrm{R} / \mathrm{h}=0.5$ についての結果は、図 - 13 に示される。図-9や10 の流速振幅の空間分有で被夏工の 空隙の縮流効果により激しく乱された空隙㳯の小さい場合において、0.8 慣性力の $1.5 \sim 2.0$ 倍程度の抗力が作用する。空隙率の大きい場合は、 波形勾配を大きくしても設置位置を高くしても慣性力以上の抗力が 作用せず、図一 9 や 10 で示さ机万程度の被復工周辽の縮流では、 慣性力を上回る抗力は生じないことがわかる。

以上のことから、被嗄工ブロックの安定性について考えると、波 高減敦が大きく、慣性力を上回る抗力が作用するような条件の場合 0.2 （被覆工の空䏚摔が小さく設置水深が大きい）に対しては、波高の 減衰効果は期待できるが、㥜性力を上回る抗力の增加により被嗄工 には、非常に大きな揚力が作用し、被覆工の本来の目的である潜堤 構成材料の敬乱防止のために安定性を考虑すると不経济な被復工ブ ロックとなる。従って、被要工に消波機能を期待せず、空隙を設け

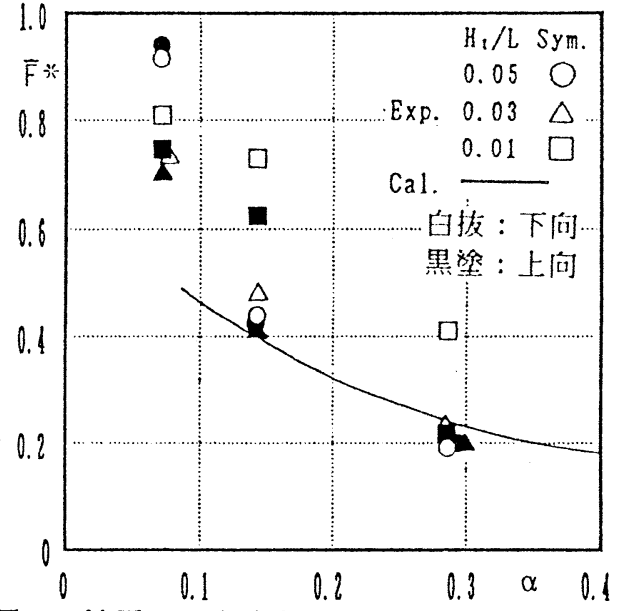

図-13 被覆工の空隙棌を変化させた場合の 被罥ブロックに作用する揚力の変動特吽. $(R / h=0.5, B / h=25.2, h / L=0.18)$

ても被覆機能に支障がなければ、空腺を設けることによりあまり大きな抗力も作用せず経済的な被覆工が設計で きる。また波高減衰の方法としては、被夏工内部に流体運動が伝達するため潜堤構成材料の透水性を利用して波 高減亭させる力法や、天端上で強制确波させるなどの方法を用いる方が、より合理的な被復工ブロックの利用方 法であると考えられる。

5. 粘語

i)入射波波長に対して十分大きい長さを有し、入射波波長に対して十分小さい空隙が設けられている被覆工上の 波高減衰は、被覆工の設置位置が波動運動の激しい水面に近く、波形勾现が大きいほど波高減衰（エネルギ一逸 散率）が大きい。

ii)水深の中ごろに設置された被婹工上を伝播する波は、沖侧からほほ入射波波長の3 倍程度の领域で減衰が大き く、それより岸側はほとんど減衰せずに伝播する。

iii)入射波波長に対して十分大きい長さを有し、入射波波長に対して十分小さい空隙が設けられている被得工上 の波高隇衰率が最大となる空䏚深は、5 10\%程度である。

iv)被覆工周辺での鉊直流速振幅は、波高減衰があまり大きくない場合です被覆工の縮流効果によって㺫速される。

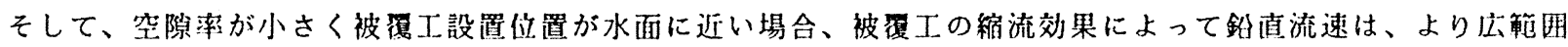
でより大きく加速され、この流速に伴う抗力の仕东で波動はエネルギーを逸散し、波高隇衰を生じるものと考元 られる。

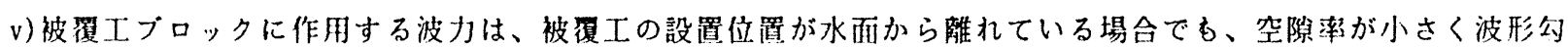
配が大きけ机ばブロックに慣性力以上の抗力が作用する場合がある。逆に被覆工の空陣深が大きい場合（30\%以 上）ブロックには慣性力以上の抗力ははとんど生しない。

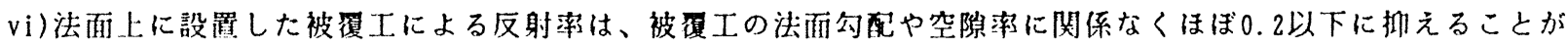
できる。しかしながら、被覆工の空腺菠が大きい場合、透過する波動はかなり大きくなるため被復工背後での波 動の制御を考虑する必要がある。

<参考文献 >

1)中村孝幸;薄肉物体まわりの波浪境界值間題に関する解析法,第30回海岸工学講演会論文集, pp. 410-414,1983. 2)中村孝幸·野村周吾; 規则配列された 3 次元物体まわりの波浪境界值問题の解析法,第37回海岸工学論文集, pp. 5 $24-528,1990$. 